\title{
Paths of Evolution of Territorial Identity. The Case of Former Towns in the Katowice Conurbation
}

\author{
Valentin Mihaylov ${ }^{A^{*}}$, Jerzy Runge ${ }^{A}$, Robert KrzysztofikA, Tomasz Spórna ${ }^{A}$ \\ Received: June 05, 2019 | Revised: August 05, 2019 | Accepted: August 06, 2019
}

DOI: $10.5937 / g p 23-22018$

\begin{abstract}
In this study we focus on the evolution of the identity of those urban neighbourhoods which have formerly been separate towns. This problem is discussed using the example of the polycentric conurbation of Katowice in southern Poland, which came into being because of its mining and industrial functions. The administrative integration of this multi-level polycentric urban system is the primary background for the development of those neighbourhoods that used to be separate towns. Assuming that changes in legal and administrative status may have certain consequences regarding the social connections and identity of such neighbourhoods, this study aimed to identify such places within the analysed region. The authors also attempted to construct paths of local identity for such spatial entities, confronting them with the thesis that economic factors make them relatively homogeneous. The implementation of new development factors and the paradoxical diversity of the identities of the former towns in this mining-industrial region are also significant elements of the region's social transformation in terms of economic and spatial development.
\end{abstract}

Keywords: territorial identity; former towns; neighborhood; Katowice conurbation

\section{Introduction}

Territorial or socio-spatial identity is a concept that implies dialectical interlinks between people's social belonging and people's attachment to the place. From the 199os, peoples' identity became a prism through which other topical aspects of contemporary life could be identified and examined (Bauman, 2001). If the 1990 os were a time of an "explosion of identities" (Hall, 1996; Bauman, 2001), the following years saw their rapid and deep implementation in various spheres of social life. As noted by Castells (2010), people's identity and their attachment to their spatial and cultural environment carry considerable weight in the politics and institutions of every country. This remark concerns territorial identities on every spatial scale from neighbourhood to metropolitan area and region - as well as the links between them.

The identity of towns or metropolises is largely based on hierarchical or network city models $(\mathrm{Pu}-$ main, 1992). This phenomenon is especially visible in the case of polycentric urban regions (PURs) ${ }^{1}$ created in the past on the basis of specialized functions of mining and heavy industry. In areas with a high con-

\footnotetext{
Polycentric urban regions (PURs) in Europe have differing origins. This category also includes such urban regions as post-industrial conurbations.
}

\footnotetext{
A University of Silesia in Katowice, Bankowa 12, 40-007 Katowice, Poland

* Corresponding author: Valentin Mihaylov, e-mail: valentin.mihaylov@us.edu.pl
} 
centration of deindustrialised cities and towns, specific relations and models of territorial identity have been moulded (Van Houtum \& Lagendijk, 2000; Musterd \& Van Zelm, 2001). In the case of cities and regions going through economic and social transformation, the issue of collective identification is an increasingly significant accent in projects that involve branding and re-branding their spatial image (Knapp, 1998; Murzyn-Kupisz \& Gwosdz, 2011; Goess et al., 2016). Relations between identity and heritage tourism in the post-industrial context play an activating role in the process of cultivating and promoting urban identity, as has been pointed out by Jones and Munday (2001), Ćopić et al. (2014), Berger and Pickering (2018), Bosák at el. (2018) etc.

Traditionally, former towns and labourers' neighbourhoods in industrial regions generated natural conditions for the reproduction of local culture (Wódz, 1998; Dokoupil at al., 2012; Faull, 2012). The identity of industrial towns and neighbourhoods was often associated with social class, but this model changed under the influence of new construction and the arrival of new residents (Robertson et al., 2008). In the nineteenth and the first half of the twentieth century there was a convergence between place of work, place of living, and profession (for example, miner, steelworker, textile worker). There was one identity, obvious and unquestionable. In the second half of the twentieth century this system underwent changes. Researchers focused on the social changes that were taking place in these regions, their towns and labourers' neighbourhoods in the phase of transition to post-industrialism (Bulmer, 1978) and the formation of post-coal communities (Strangleman, 2001).

In local communities based on mining and metallurgy, the transition from industrialism to post-industrialism required a search for new resources for socio-spatial development. One of them is the concept of territorial identity. The relations between old and new elements of identity and attempts to reconcile them in the interest of the future pose an important developmental dilemma. An appropriate research tool is the idea of transition from thick to thin regional identities (Terlouw, 2012). Thick identities are represented for example by industrial regions - rooted in traditions, more conservative, and therefore reluctant to open up to change. Thin identities, on the other hand, bear to a large degree the marks of social constructivism. They are advocated chiefly by local administrative bodies, striving to create network territorial communities that are open and future-oriented.

Some spatial entities (towns and neighbourhoods) in PURs have experienced a gradual disappearance of mining-based communities. In the Ruhr area the transformation of the old identity based on coal and steel towards smart cities, green economy, university cities, cities for shopping, etc. (Goess et al., 2016) began in the 1970 s and 1980s. The development of towns and neighbourhoods in mining-based conurbations in post-communist countries (Upper Silesia, the Dąbrowa Basin, the Rybnik Coal Area, OstravaKarvina and Donbas) has followed a distinct path, especially under the influence of the socialist system introduced in 1945. Only in the 1990s were the lifestyle and work ethos that had formed in times of industrialisation disrupted under the influence of dynamic exogenous factors (globalization, European integration) and endogenous factors (deindustrialization, economic restructuring, introduction of local democracy).

Despite the significant number of theoretical and empirical works on identity on the town and neighbourhood scales, these questions remain poorly conceptualized, especially in the context of polycentric urban regions. Cultural factors in the development of demoted towns in Poland, especially material heritage and the place attachment of their inhabitants, play a mobilizing role in processes of the restitution of their urban status (Dymitrow, 2013; Dawidejt-Drobek \& Drobek, 2015). In contrast to the case of abandoned industrial towns, which disappeared from the map following the exhaustion of natural reserves, ruralization or natural disasters (Baker, 1991; Krzysztofik et al., 2015), we are interested in a different case of disappearance from the geographical map - namely, the loss only of formal urban status. This may have occurred even when a locality found itself in a period of rapid economic and demographic growth. This paradox - the loss of identity on the map of Poland occurring in circumstances of visible socioeconomic growth - represents a significant research gap, the filling of which is one of the main goals of this article.

In more specific terms, the aim of this study is to examine how the change of administrative status and processes of deindustrialisation affect former towns' identities. The Katowice conurbation in southern Poland was chosen as the study area. This is one of the polycentric regions in Central Europe founded on mining and metallurgy, and distinctly formed both spatially and functionally, similar to the Ruhr area and the Ostrava-Karvina conurbation in the Czech Republic. It appears suitable for a study of this kind because of its distinct polycentrism, the frequent changes of administrative borders in the past, and the large number of former towns. 


\section{The Katowice conurbation and its territorial identities}

The question of this area's collective identity is one of the most complex in urban, cultural and historical geography in the whole of Central and Eastern Europe. The core, internal and external zones of the Katowice conurbation cover a total of 3300 square kilometres and are inhabited by 2.5 million people (Spórna, 2018). The conurbation contains a total of 29 towns.

The larger, western part of the Katowice conurbation historically belongs to Upper Silesia, and the remainder (the Dąbrowa Basin) to western Lesser Poland. From 1742 a larger part of Silesia came under the rule of Prussia, and later Germany. On a present-day map, historical Silesia extends from Lusatia in eastern Germany to the rivers Przemsza and Brynica in southern Poland; part of it also lies in the Czech Republic. Lesser Poland, in turn, is a large Polish historical region with its capital in Cracow (Fig. 1).
After the Congress of Vienna (1815) the area of historical Lesser Poland was divided between Russia and Austria-Hungary. The westernmost, mining-based and industrialized piece of the Russian partition came to be known in the nineteenth century as the Dąbrowa Basin (Zagłębie Dąbrowskie). The modern-day Katowice conurbation contains what was, until 1918, the meeting point of the borders of three great nineteenth-century empires - Russia, Prussia and Austria-Hungary. Because these events took place in a period of great socioeconomic transition they significantly influenced the diversity of identities in the region.

Between the First and Second World Wars the area of the present conurbation remained politically divided between Poland and Germany. After the Second World War all of the present-day towns were finally incorporated into a single region, called the Upper Silesian In-

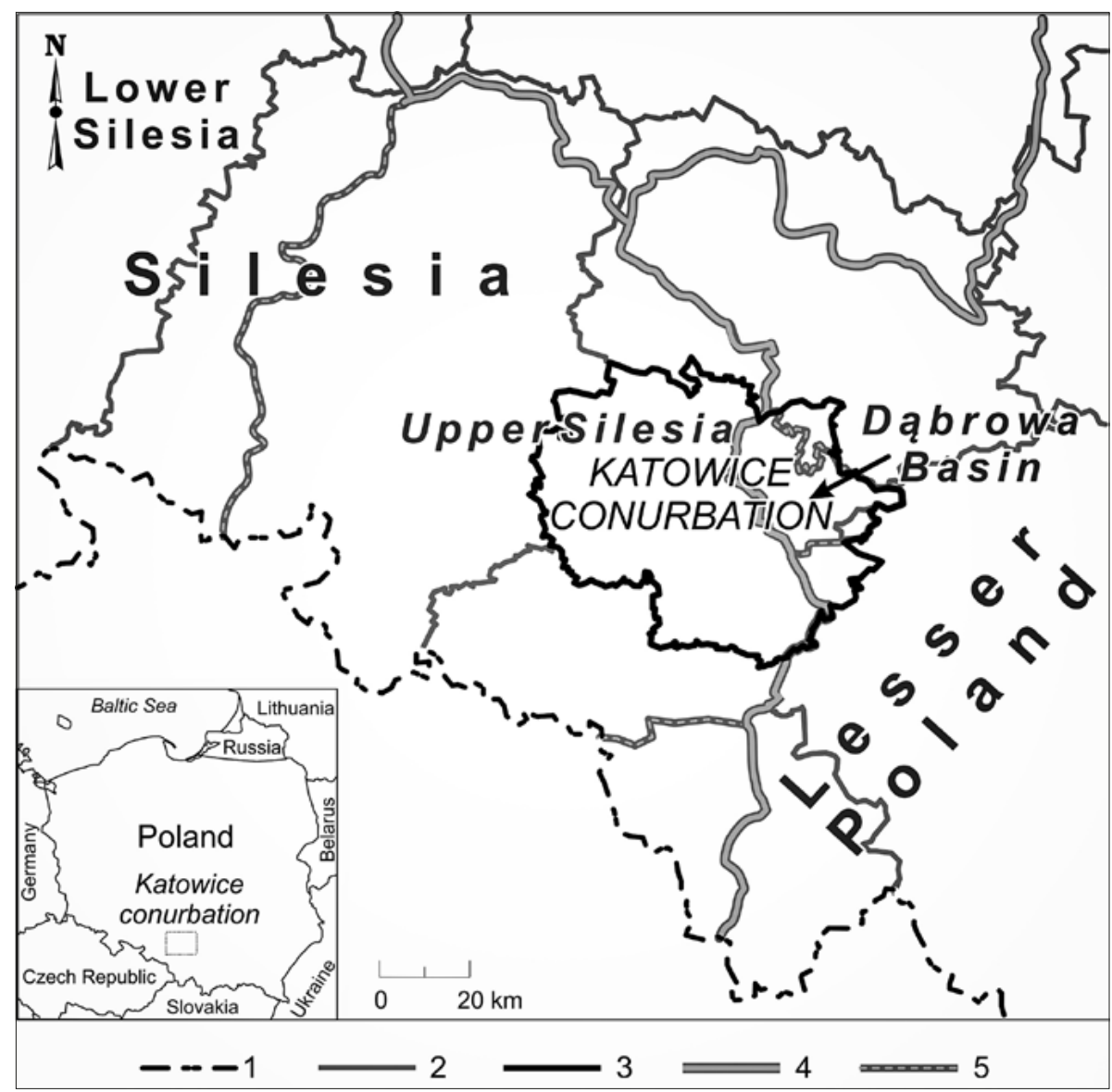

Figure 1. Geographical location of the Katowice conurbation against contemporary administrative division and historical regions

Source: Authors's elaboration Legend:

1 - state boundary; 2 - voivodeship boundary; 3 - boundary of the Katowice conurbation; 4 - boundary of historical regions within contemporary Poland; 5 - major historical sub-regions. 2 - boundary of the Katowice conurbation; 3 - municipal boundary;

* - boundary of Dąbrowa Basin - in a narrow understanding; ${ }^{* *}$ - boundary of Silesia within contemporary Poland. 
dustrial Region, which stressed the economic rather than the sociocultural dimension of regional identity.

Due to its polycentrism, spatial identification within the conurbation is even more dispersed at lower levels (Mihaylov \& Runge, 2018). The identity of many present-day towns is based on a mechanical summation of the identities of neighbourhoods. For example, Sosnowiec - the chief city of the Dąbrowa Basin - represents a polycentric structure with as many as 18 settlement units, including seven former towns and two former urban settlements (Stankiewicz, 2014).
Almost all towns of the conurbation achieved their current administrative and territorial form in the twentieth century, as a result of: 1) the merger of a few more or less equivalent settlement units (as in the case of Ruda Śląska and Dąbrowa Górnicza); 2) administrative incorporation into a larger economic centre of smaller towns, villages, neighbourhoods and labourers' settlements, some of which have a strong innerurban or inner-neighbourhood identity (as with the spatial development of Katowice, Piekary Śląskie, Sosnowiec and Jaworzno).

\section{Data and methods}

Our research was based on materials obtained during field studies, a review of the subject literature, cartographic and internet materials.

The research procedure consisted of two major phases. The first one concerns inventorying of spatial entities representing the category of former towns in the Katowice conurbation and review of their development, mainly in respect of the granting and rescindment of urban status. The set of former towns, based on the analysis of 242 settlements in the territory of the Katowice conurbation, was verified. Former towns were selected on the basis of legal and administrative criteria, omitting the morphological and economic ones. The identification of this category was made on the basis of maps from the State Archives in Katowice and selected publications (Srokowski, 1948; Zmiany administracyjne miast i osiedli 1918-1963, 1964).

The second phase of our research concerns selected case studies of examples of former towns with different locations, histories and degrees of socioeconomic transformation. We indicate specific aspects of the identity of the following former towns:

in Upper Silesia - Nowy Bytom and Wirek, neighbourhoods lying in the geometric centre of the polycentric city of Ruda Śląska, and Murcki, a small neighbourhood on the outskirts of Katowice, completely separated from the rest of the city;

in the Dąbrowa Basin - the Grodziec neighbourhood in Będzin (lying on the outskirts, but physically connected to the central town space), and Modrzejów and Niwka, lying on the boundaries of Sosnowiec and Mysłowice, and at the same time on the boundary between Upper Silesia and the Dąbrowa Basin.

The study of the selected neighbourhoods was based on an analysis of characteristics such as: the location, genesis and historical evolution of the settlement; economic restructuring in the post-industrial period as a determinant of the continuation or disruption of tradition; valuable examples of residential or industrial architecture from the era of industrialization; actions taken to revitalize the cultural or industrial heritage; and formal organizations and informal groups promoting local identity (Table 1). These characteristics were chosen as they impact the functioning of the neighbourhood in the social and cultural dimensions, and are therefore significant for the preservation of strong place identification.

\section{From a small industrial town to a city neighbourhood. Paths of preservation and decline of local identity}

In this part we focus on the evolution of chosen elements of the collective identity of former towns in relation to the change in their formal status (lowering of their administrative and political rank). Generally, obtaining urban status strengthens residents' selfperception and serves as evidence of, among others, the successes achieved in the place's development. Because the subject of our analysis is restricted to the identity of former towns founded on mining and industry, a more specific question arises: to what extent do contemporary socioeconomic conditions permit the preservation of traditional identity, and how much do they force it to be redefined?

The Katowice conurbation contains a total of 25 former towns and ten former urban settlements ${ }^{2}$. Among them, two towns (Niwka and Modrzejów) received and lost their town charters in the eighteenth and nineteenth centuries, becoming incorporated into the new-

\footnotetext{
2 Urban-type settlements form a category that existed in the communist era, in the 1950s and 1970s, in some of the former communist countries (the USSR, Poland and Bulgaria).
} 
ly created city of Sosnowiec in the twentieth. Among the towns that are now neighbourhoods of other larger ones, only one town in the Katowice conurbation Szczakowa - received formal urban status between the world wars. The remaining centres of this type received their status after World War II (in the 1950s and 1960s), this being associated with their dynamic demographic and economic growth. The great majority of them lost urban status during the aforementioned administrative reform of the mid-197os (Fig. 2).

In the conditions of a dynamically expanding polycentric urban network, moreover one covering a relatively small area, the short times for which localities retained town status resulted from their limited room for territorial growth. This is one of the fundamental reasons for their rapid incorporation by a neighbouring, larger urban system, although their fate was sometimes decided by a subjective political factor. The region's polycentrism means that the identity of many of today's neighbourhoods or former towns is shaped under the influence of adjacent cities. For example Niwka and especially Modrzejów, which lie in the Dąbrowa Basin, have strong functional connections with neighbouring Mysłowice, which is in Upper Silesia. The centre of Modrzejów is just one kilometre from Mysłowice, but 5-6 kilometres from the centre of Sosnowiec, the city of which it is a part.

Despite the different periods in which urban status was enjoyed, both in the consciousness of present-day inhabitants and in the physical space, there is specific evidence of urbanism and historical autonomy, such as a market square, town hall and labourers' settlements (Runge \& Runge, 2015). Beginning from the 196os and 1970s the communities of former towns have been forced to coexist in new institutional and spatial-administrative boundaries, balancing between two territorial identities. On the one hand, there is the identity of one's own neighbourhood (or

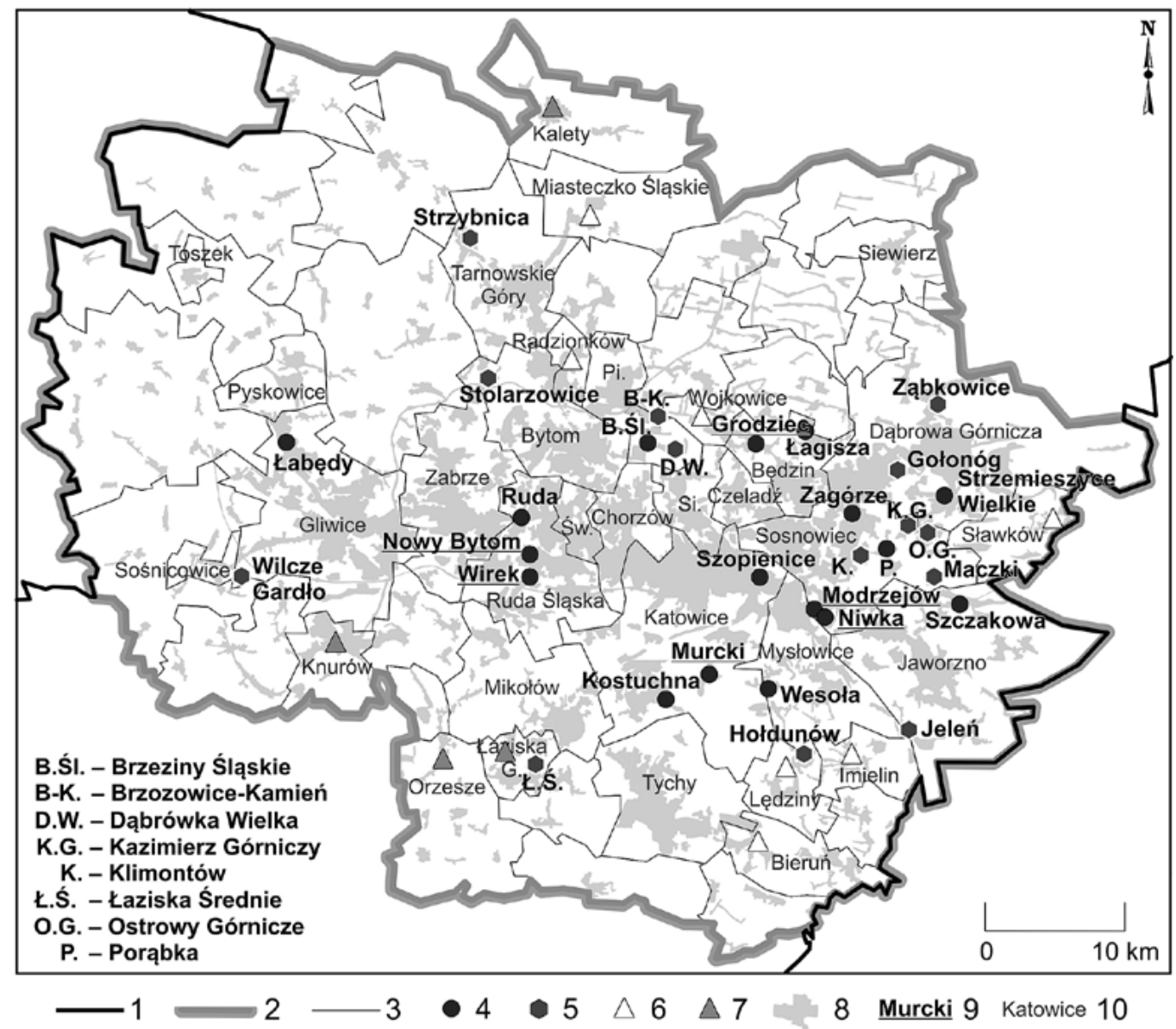

Figure 2. Former towns and urban settlements in the Katowice conurbation Source: Authors's elaboration. Legend:

1 - provincial boundary; 2 - boundary of the Katowice conurbation; 3 - municipal boundary; 4 - former towns, now neighbourhoods of other towns; 5 - neighbourhoods that until the 1970s had the status of urban settlements; 6 - former towns that regained urban status in the second half of the twentieth century; 7 - places granted urban status in the second half of the twentieth century; 8 urbanised areas; 9 - case studies; 10 - names of present-day towns and cities.

Abbreviations of towns: Łaziska G. - Łaziska Górne; Pi. - Piekary Śląskie; Si - Siemianowice Śląskie; Św. - Świętochłowice. 
former town). In spite of the fact that this existed for only a short period in the past and was predominantly a small-town identity (including affiliation to a particular industrial works), it was more pronounced, providing a greater degree of autonomy, rooted especially in material heritage and spatial distinctiveness. To the present day many inhabitants of outlying neighbourhoods do not say that they are travelling to the 'centre', but to Katowice or Sosnowiec, for example. On the other hand, it has become necessary to adapt to the new neighbourhood identity, usually administratively imposed from outside, and not by the community's own choice. This provides a weaker feeling of certainty and rootedness, is less grounded in tradition, and dissolves in the large polycentric space and the institutionally empowered identity of the town, conurbation and metropolis. Incorporation into a larger urban unit has also brought advantages, such as affiliation to a more politically and economically powerful community that provides greater opportunities for choice and accomplishment.

At the beginning of the twenty-first century the large group of former towns exhibits diversity in terms of area, population, morphological features of urban space, level of economic development, and cultural heritage. In spatial terms, most of them are clearly separated by the rest of the city by which they were incorporated. Neighbourhoods compared in our study demonstrate a different state of chief factors sustaining their local identity. In general, the factors discussed here are poorly represented in Modrzejów (Neighbourhood Council, local website and online forum) and Niwka (Neighbourhood Council and parish of the Roman Catholic Church). The former towns from the Silesian part of conurbation (e.g. Murcki,
Nowy Bytom and Wirek) are in more favourable situation. For instance, all these neighbourhoods have valuable architectural monuments or complexes.

Not just our case studies, as it is shown in Table 1, but Kazimierz Górniczy, Klimontów, Zagórze, Łabędy and other former towns have also been left without their traditional economic base (due to the closure of a mine or other large plant). Currently, the working age population is mostly employed in services and in newly opened, technologically advanced industrial plants. Due to deindustrialisation, the inhabitants from many former towns are experiencing eradication and erosion of strong territorial attachment and identity formerly connected to work in coal mines. Simultaneously, Nowy Bytom, Wirek, Strzemieszyce Wielkie, Łabędy and Łagisza still have functioning mines, steelworks, electric power plants or new factories, providing a basis for continuation of the traditional industrial identity.

After 1990 the decentralisation of the political system reinforced and provided legal guarantees for the role of local authorities. An important tool of their spatial policy was reference to the former urban identity, for such purposes as protecting and restoring historical buildings and monuments, and promoting interest in history and local heritage. Despite the policy of centralization in the 1970s, which largely suppressed possibilities of independent development, some local communities continue to display a strong connection to the place where they live. Since 1990 a growth of interest in heritage has been observed in some of these places. A number of examples from both the core and the periphery of the Katowice conurbation demonstrate the strength of the remaining sense of identity.

Table 1. Selected factors sustaining the identity of former towns

\begin{tabular}{|c|c|c|c|c|c|c|}
\hline Indicator & Grodziec & Modrzejów & Murcki & Niwka & Nowy Bytom & Wirek \\
\hline $\begin{array}{l}\text { Clear spatial separation from the } \\
\text { rest of the city }\end{array}$ & + & - & + & - & + & + \\
\hline $\begin{array}{l}\text { Valuable architectural monuments } \\
\text { or complexes }\end{array}$ & + & - & + & - & + & + \\
\hline $\begin{array}{l}\text { Revitalization of architectural } \\
\text { monuments and old industrial } \\
\text { constructions }\end{array}$ & + & - & - & - & + & + \\
\hline Operating mine / steelworks & - & - & - & - & + & + \\
\hline Neighbourhood Council & - & + & + & + & - & - \\
\hline $\begin{array}{l}\text { Parish of the Roman Catholic } \\
\text { Church }\end{array}$ & + & - & + & + & + & + \\
\hline Neighbourhood association & + & - & - & - & - & + \\
\hline $\begin{array}{l}\text { Neighbourhood websites and online } \\
\text { forums }\end{array}$ & + & + & + & - & - & + \\
\hline Neighbourhood House of Culture & + & - & + & - & - & - \\
\hline
\end{tabular}

Source: Author's elaboration. 


\section{Case studies}

\section{Former towns that are now central neighbourhoods of a polycentric city: Nowy Bytom and Wirek}

Because of the scattered location of residential areas and the large number of industrial plants, the space of Ruda Śląska represents a residential-industrial conglomerate. It is a typical polycentric city, and consists of 11 neighbourhoods, including three formerly separate towns. The spatial distinctness of these neighbourhoods is so marked that their names appear on signs on the roads leading into them (Fig. 3).

In a sociological study by Bierwiaczonek and Nawrocki (2008) concerning perceptions among residents

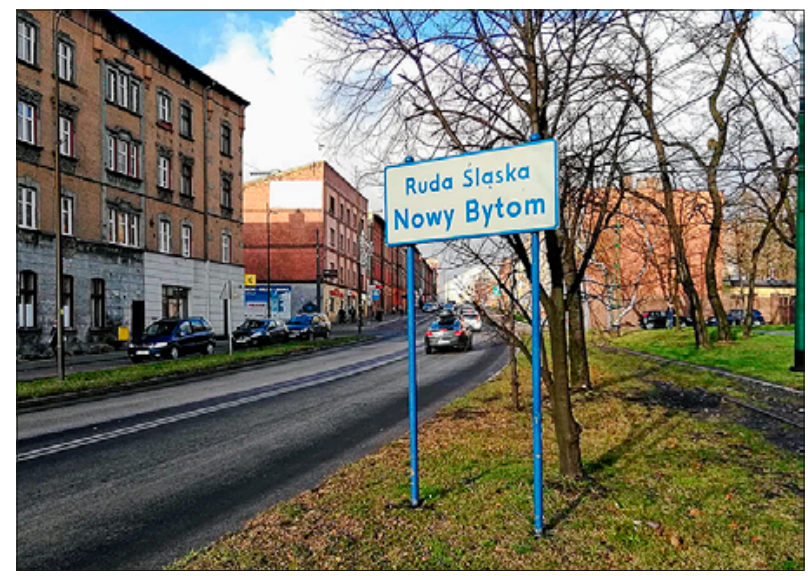

Figure 3. Sign on the boundary with Wirek showing the name Nowy Bytom, larger than that of the town Ruda Śląska

Photo: Authors

of Upper Silesian towns of where the town centre lay, the most varied responses were received in Ruda Ślaska. Because the town represents a cluster of former localities, respondents indicated entire neighbourhoods in their answers. Nowy Bytom was identified as the centre by $26 \%$ of respondents, while second and third place were taken by the Plaza shopping centre in Wirek and the neighbourhood of Wirek as a whole.

The settlement of Nowy Bytom ('New Bytom') was created in the independent Polish state in 1922 on land that had previously belonged to Bytom. In the plebiscites - in contrast to Murcki, for example, where the Polish option was chosen by the vast majority - the results for the preferred national affiliation of Nowy Bytom and Wirek were very close.

In 1959, Nowy Bytom (to which Wirek had already been joined) and Ruda formed the core of the new city of Ruda Śląska (its name meaning 'Silesian ore'), and today they are adjacent neighbourhoods of that city. The 'leading' position in the polycentric town is a sig- nificant administrative base, facilitating the cultivation and exposition of heritage. The two central neighbourhoods of Ruda Śląska can boast impressive urban architecture (Fig. 4). They also contain preserved groups of labourers' houses from the second half of the nineteenth or early twentieth century, built from red bricks, a characteristic of the Upper Silesian identity. A significant role in maintaining the local identity is played by inner-neighbourhoods - the workers' settlements of Kaufhaus in Nowy Bytom and Ficinus in Wirek, which are now subject to conservation orders and are popular among tourists. Moreover, the

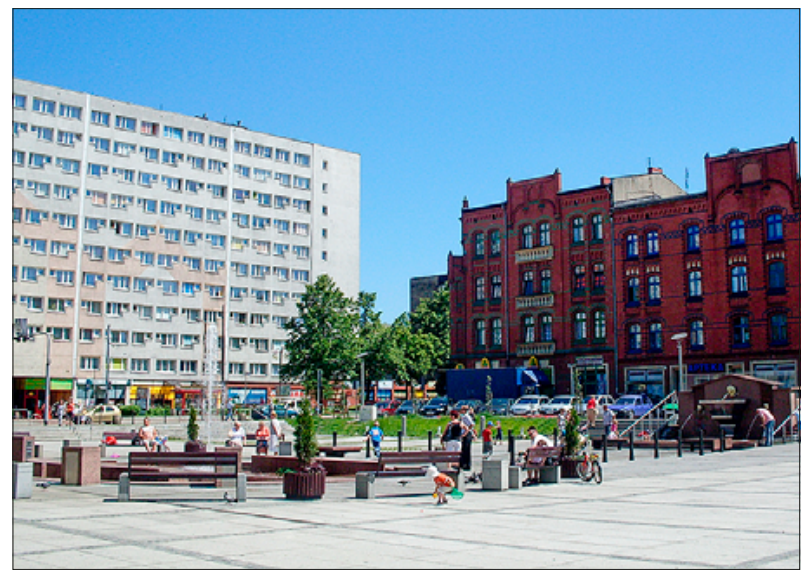

Figure 4. On the main square in Nowy Bytom, restored red brick tenement houses from the early twentieth century alongside residential blocks from the socialist modernist era Photo: Authors

steelworks and mines are still operational, enabling the continuation of the traditional identity shaped around work in these industries.

\section{Murcki-a town incorporated into the regional capital}

Murcki is a neighbourhood of Katowice which is distinguished from the other former towns of the conurbation by its geographic location. It is surrounded on all sides by areas of forest (Fig. 5), and is thus described as a forest settlement. Murcki is a model example of evolution from a mining town to a peaceful, outlying neighbourhood with recognisable architecture and a network of streets preserved from the early twentieth century (Fig. 6). The origins of mining in Murcki date back to the 1740s, and maybe even further (Jaros, 1984). It is considered to be the place where coal mining in Upper Silesia began. In the interwar period Murcki became part of Poland. The settlement had a coal mine and brickworks, owned by the Duke 
of Pszczyna. Murcki became a separate municipal district in 1924. It was the wealthiest Silesian district at the time, supported by the taxes paid by the mine owner (Chałasiński, 1935).

The community of Murcki was a purely industrial one. It was inhabited exclusively by the workers and clerks of the mine. Only those who worked for Murcki's owner could obtain a dwelling there, and they would have to vacate it on termination of their employment. Murcki was a community without leaders or an intellectual class. After completing the common school, workers' children themselves went to work in the mine. Before the Second World War, Germans and Protestants accounted for only a small percentage of the population. In the early 1930s there were 3000 Catholics and just under 200 Protestants living in Murcki. The latter group included the mine owner (Chałasiński, 1935).

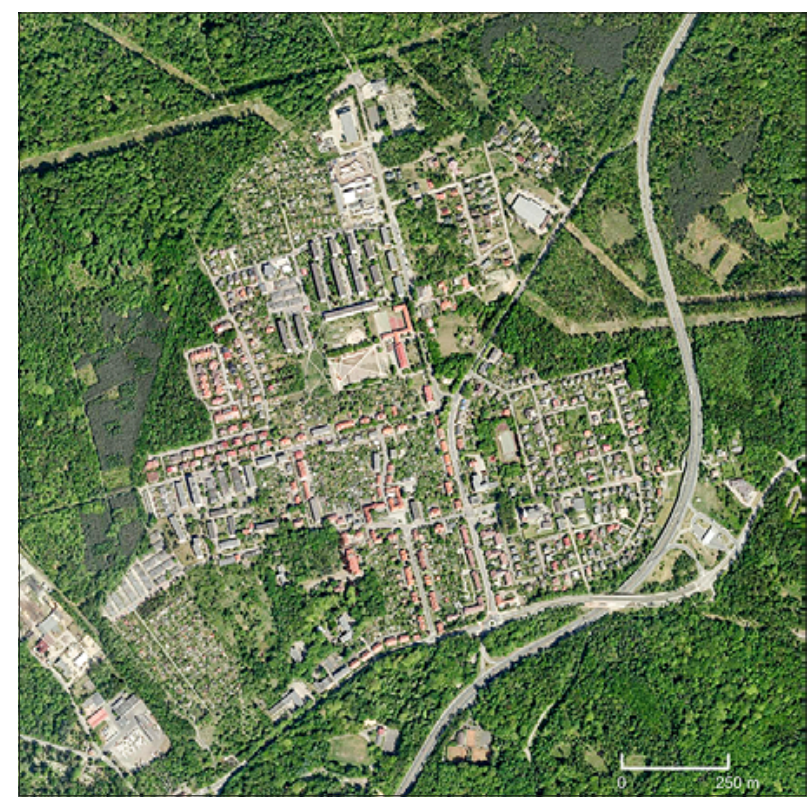

Figure 5. Built-up area of the former mining town of Murcki

Source: geoportal.gov.pl

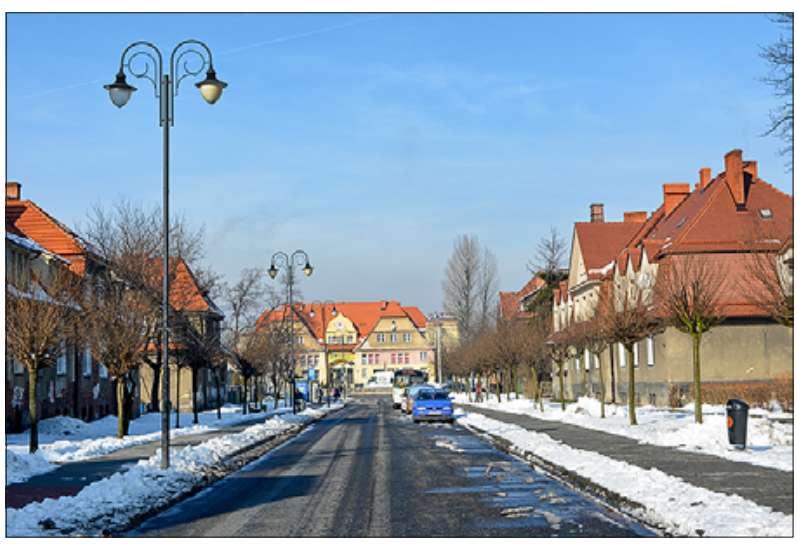

Figure 6. Wolności street, one of the representative streets of Murcki (pictured at January 2019) Photo: Authors
After the Second World War mostly young people from other regions of Poland came to work in the mine. The settlement established deeper social and economic connections with nearby cities. Increasing numbers of people with higher education, and fewer manual workers, settled in Murcki. In 1967 Murcki was granted a town charter, but just eight years later it was incorporated into Katowice. The latter part of the communist period saw the closure of the mines, which had been the main integrating factor in the life of the neighbourhood and a source of significant funds supporting its cultural life and appearance (Nawrocki, 2006).

Although the labourers' houses and the whole layout of the mining town were preserved almost unchanged, their current state indicates a need for revitalisation. In 2015 an application was made for the urban layout of Murcki to be listed as a protected site. However, this would entail a number of restrictions and obligations. Some residents do not support the idea, since it would mean that every renovation or thermal insulation project would need to be assessed by a conservator of monuments in Katowice.

\section{A deindustrialized former town}

\section{in the Dąbrowa Basin-Grodziec}

Grodziec is an old feudal village, founded on the slopes of Dorotka hill, where a characteristic Baroque church stands. During the industrialization of the nineteenth century a brewery, a zinc smelter, the first mines, and one of the first cement works in Europe were established there. The morphological structure of the former town includes detached houses, labourers' settlements from the turn of the twentieth century (Fig. 7), and prefabricated blocks of flats from the socialist era. In the 1920 s proposals were made for Grodziec to be given urban status, but the local peasants and workers considered this unnecessary. It finally became a town in 1951, but a quarter-century later it was incorporated into Będzin.

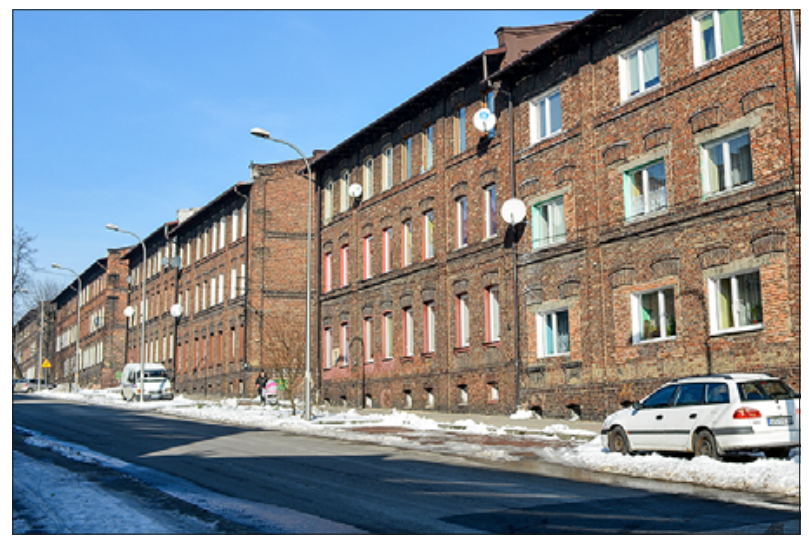

Figure 7. About 20 red brick family apartment houses are preserved at the Konopnicka street in Grodziec Photo: Authors 
In the 1990s some lobbied for the return of Grodziec's autonomy, and a 16-person committee was registered at the provincial court. These efforts were largely inspired by the successful campaign of nearby Wojkowice to secede from Będzin. Grodziec has lost almost its entire economic base, and nowadays serves primarily a residential function. This would impair its functioning as a separate town, a fact of which residents were and still are aware. In the not-too-distant past the main factor in the functional integration of the neighbourhood was the mine. The miners' holiday, celebrated on St Barbara's Day was an event of significance for the whole neighbourhood. In the now postmining community, a mining-related element was introduced with the founding of a modest monument to the Grodziec mine (2017), together with a symbolic march by the miners' band on 4 December. This, however, is a St Barbara's Day without active miners or an operating mine. Grodziec thus represents a typical conservative identity - one that feeds off the past, not the present. There is a powerful sentimentalism towards the Grodziec coal mine that closed in 1999.

Regarding the organization of cultural life, Grodziec is distinguished by the presence of important elements that sustain sociocultural individuality and place attachment (Table 1). The energy of social activity is directed towards protecting and promoting the post-industrial heritage. Thanks to the work of local activists, in 2017 funds were obtained for the revitalization of a historical 40-metre-tall water tower offering views of the surrounding area. For many years a project was promoted to create a modern cultural zone on the site of the old cement works; however, these plans lack support on Będzin town council.

\section{Former twin towns on the boundaries of Upper Silesia and the Dąbrowa Basin - Niwka and Modrzejów}

Niwka and Modrzejów are two feudal towns created in the eighteenth century and incorporated into Sosnowiec in the twentieth. They are "twin towns", linked by a similar genesis and economic functions and by their spatial proximity.

From the first half of the nineteenth century Niwka was one of the more important mining and industrial centres of the Dąbrowa Basin, based on coal mines, an ironworks and a factory producing mining machinery. In the 1850s, in Henryków, a no longer extant part of Niwka, the Polish Kingdom's first steelworks was opened.

Historical memory in Niwka remained active when, in the interwar period, attempts were made to restore its urban status, and to incorporate Modrzejów, which already lay within the borders of the adjacent city of Sosnowiec, with its population of 100,000. However, these efforts were not successful. Modrze- jów, in turn, was based on commerce and a service economy, and had a largely Jewish population. It was one of what were known as the Jewish towns in former Poland, having a synagogue but no Catholic church. Niwka was a decidedly Polish, Catholic, working-class community. Catholics from Modrzejów belonged to the parish in Niwka, while Niwka's Jews belonged to the Modrzejów kehilla. When Niwka was incorporated into Sosnowiec in 1953 it became one of that city's peripheral neighbourhoods. Two-thirds of Niwka's inhabitants settled there during the communist era. At present, Niwka and Modrzejów are associated with the regional congress centre of the Jehovah's Witnesses, built in the late 1990 s on the boundary of the two neighbourhoods. Although the fact that Niwka held urban status in the eighteenth century was mentioned in some scholarly publications, until the beginning of the twenty-first century it was generally unknown to the local community (Krzysztofik, 2015).

More important to the residents of Niwka and Modrzejów was the identity based on mining and industrial labour. As in the case of other neighbourhoods and towns of the Katowice conurbation, in the 198 os the landscape came to be dominated by prefabricated blocks of flats built for industrial workers. The layout of Niwka's original eighteenth-century market square, in the southern part of the neighbourhood, was completely erased. The spatial layout of Modrzejów has also been significantly destroyed, and is no longer perceptible to the uninvolved observer. The Jewish history of Modrzejów is well known to the present-day inhabitants, but since there is no Jewish community nowadays that historic component of the neighbourhood's identity is generally marginalized.

As in the case of Grodziec, the identity of today's Niwka and Modrzejów has a sentimental character, being grounded in the past (Fig. 8). The mine not only organized the neighbourhood's economy, but played important roles in social, municipal, cultural and educational life. Today, an attempt to revive that role is being made by

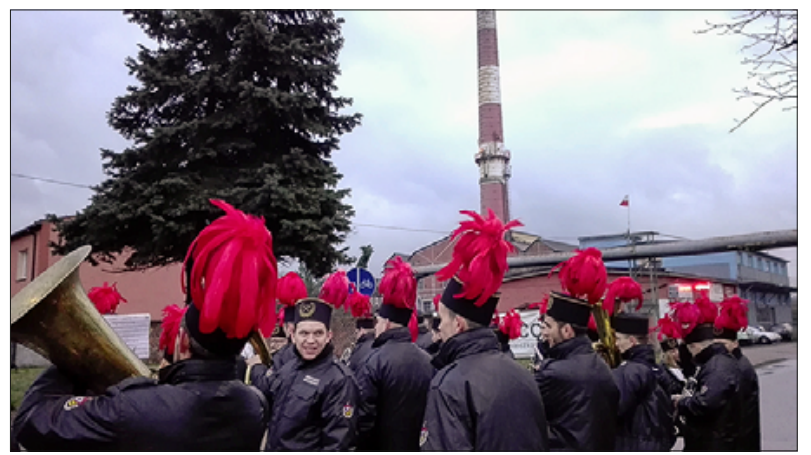

Figure 8. Traditions in a post-mining neighbourhood - a mining orchestra goes through Niwka on St. Barbara's Day (December 4) Photo: Authors 
the council of the city's South District, which consists of Niwka, Modrzejów and two other neighbourhoods.

Due to the revitalization of identity in Niwka and Modrzejów, there are currently no "secessionist" movements seeking to give these neighbourhoods autonomous status. In the 1990 os and in the early years of the twenty-first century there existed only informal ideas of detaching Niwka from Sosnowiec.

\section{Discussion and conclusion}

In this article we have attempted to perform a problematization of the issue of the identity of former towns in a polycentric urban region - an aspect of territorial identity that is rarely addressed and is not readily subject to both empirical studies and theoretical generalizations.

Historical regions still play an important role in maintaining the polycentric character of identity. In the Katowice conurbation, existing regional identities - firstly that of Upper Silesia, followed by that of the Dąbrowa Basin - have gained popularity and are sustained by various formal initiatives of the mayors of cities in both regions. In the light of the Terlows' conception (2012), at this level one may speak of the existence of a mixture of thick and thin forms of territorial identity.

This situation is close to the model found in the Ruhr area. In the case of the German PUR, however, there did not exist historically such profound differences in spatial organization as may be seen in the material heritage of Upper Silesia and the Dąbrowa Basin, due to the cultural and material dissimilarity between Prussia and Russia. The largest city of the Czech mining conurbation, Ostrava, now contains (alongside other neighbourhoods) five former towns. Through the city runs the historical boundary between Moravia and Silesia (between the former towns of Moravská Ostrava and Slezská Ostrava). At present all of them are administratively distinct neighbourhoods. This is one of the fundamental differences compared with the former towns of the Katowice conurbation, of which only a quarter are administrative neighbourhoods. This is evidence of their high degree of incorporation into larger cities.

In those neighbourhoods in the Katowice conurbation which lost their status as separate towns in the 1970s, thick identities are grounded in the culture and daily life of the neighbourhood, although the industrial - and particularly mining - culture in which their roots lie are now absent in many places. As in the cases of Grodziec, Niwka and Murcki, the tradition of celebrating the miners' holiday is continued, but the absence of an operational mine means that those taking part are retired miners.

Like in the Katowice conurbation, some towns in the Ruhr area lost their autonomy in the significant administrative reorganisation of 1975 (Keil \& Wet- terau, 2013). As regards the conditions under which traditional identity is maintained, compared with the German coal-mining conurbation (Pasternak, 2008), the situation in the Katowice conurbation is more complex. While the last deep coal mine in the Ruhr area closed in 2018, the traditions of many urban neighbourhoods in Upper Silesia especially are still based on a working community rooted in the coal, iron and steel industries.

The findings in this study confirm the conclusion of Terlouw (2018) that local identity discourses not only explain the characteristics of the local community, but also suggest a developmental path. The basic issues that we have investigated include social changes, such as the greater socioeconomic integration in the polycentric urban region, the influx of migrating workers, the grater spatial mobility of inhabitants, and diversification of the professional structure. These phenomena were exemplified by several case studies, which indicated that administrative incorporation is a long-term factor that weakens local identity in many cases. In spite of certain common features, each one is a specific case, and hence one should be cautious in making broader generalizations. Nonetheless, they provide grounds to assert that the evolution of the identity of residents of former towns may take various paths and have various outcomes, since it depends on a local set of socioeconomic determinants. We have therefore distinguished several phases in the development and social transformation of the former towns in the Katowice conurbation:

1. Up to 1939 - establishment of settlements and formation of valuable layers of material heritage, the shaping of a lifestyle and social structures typical of mining or steelmaking communities. This was a period in which traditional identities were formed.

2. From 1945 to 1989 - many cases of destruction or neglect of local heritage, while strong economic functions were maintained; a process of heterogenization of the local community. Erosion of the traditional economic lifestyle and identity occurred. Localities first gained and then lost their autonomy as a result of centralization. Social life was subjected to stronger influences from neighbouring larger cities . New components of identity were introduced - new residents with their own culture, socialist architecture, etc. 
3. Since 1990 - increased interest in heritage and the past, and allusion to local identity in certain political and economic actions; the loss of traditional economic functions and a search for new pillars of identity. This process is based on the principle that the community looks to the future, but is built to a large extent using elements of the past. It represents a period of transition from traditional to new paths of identity, but the proportions between old and new elements vary greatly between neighbourhoods - a phenomenon which requires more precise analysis and further research.

We can undoubtedly conclude that a change in the administrative status of a former small or mediumsized town signified a change in the social status of the community as a whole. The rapid loss of urban status and interrupted development path in the communist era was dependent on, among other factors, the dense network of towns dominated by several of the largest centres. This is particularly visible in the case of the former towns located at the core of the Katowice conurbation. In several cases, however, local communities have succeeded in regaining their lost autonomy and status as a separate town. The loss of urban status is also a factor which, although it may not fully determine local identity, at least suppresses the feeling of distinctiveness and the urban aspirations of inhabitants (DawidejtDrobek \& Drobek, 2015) and brings about relativization of the former town-based identity. Because we are dealing with localities with mining origins, another significant cause of change, although not in all of the analysed neighbourhoods, is the loss of the traditional economic function and the resulting social transformation. This necessitates reconsideration of the existing pillars of identity, and even its redefinition.

\section{References}

Baker, T. L. (1991). Ghost Towns of Texas. University of Oklahoma Press.

Bauman, Z. (2001). Identity in the globalising world. Social Anthropology, 9(2), 121-129. https://doi. org/10.1017/So96402820100009X

Berger, S. \& Pickering, P. (2018). Regions of heavy industry and their heritage - between identity politics and 'touristification': where to next? In C. Wicke, S. Berger \& J. Golombek (Eds.), Industrial Heritage and Regional Identities. Routledge Cultural Heritage and Tourism Series. Abingdon: Routledge, 214-235.

Bierwiaczonek, K., \& Nawrocki, T. (2008). 'Serca' śląskich miast. Postrzegania centrów miast śląskich. In J. Kurek \& K. Maliszewki (Eds.), Miasto i czas. Chorzów, 136-156.

Bosák, V., Nováček, A., \& Slach, O. (2018). Industrial culture as an asset, barrier and creative challenge for restructuring of old industrial cities: case study of Ostrava (Czechia). GeoScape, 12(1), 52-64. https://doi.org/10.2478/geosc-2018-0oo6

Bulmer, M. (ed.) (1978). Mining and Social Change: Durham County in the Twentieth Century. London: Croom Helm.

Castells, M. (2010). The Power of Identity, WILEY BLACKWELL. DOI: 10.1002/9781444318234

Chałasiński, J. (1935) Antagonizm polsko-niemiecki w osadzie fabrycznej „Kopalnia” na Górnym Ślasku. Studium socjologiczne. Warszawa.

Ćopić, S., Đorđević, J., Lukić, T., Stojanović, V., Đukičin, S., Besermenji, S., Stamenković, I., \& Tumarić, A. (2014). Transformation of industrial heritage: an example of tourism industry devel- opment in the Ruhr area (Germany), Geographica Pannonica, 18 (2), 43-50.

Dawidejt-Drobek, E., \& Drobek, W. (2015). Cultural aspects of urban restitution in Poland. In R. Krzysztofik \& M. Dymitrow (Eds.), Degraded and restituted towns in Poland: Origins, development, problems. Gothenburg: University of Gothenburg, 37-59.

Dokoupil, L., Nesládková, L., \& Lipovski, R. (2012). The Difference in Natural Reproduction Between Industrial and Agricultural Regions during the First Demographic Transition: 1881-1913 (the case of the Ostrava agglomeration). Romanian Journal of Population Studies, 6 (1), 25-50.

Dymitrow, M. (2013). Degraded towns in Poland as cultural heritage. International Journal of Heritage Studies, 19(7), 613-631. https://doi.org/10.1080/13527 258.2012.681681

Faull, M.L. (2012). Coal mining and the landscape of England, 1700 to the present day. Landscape History, 30, 59-74. https://doi.org/10.1080/01433768.2008. 10594600

Goess, S, de Jong, M., \& Meijers, E. (2016). City branding in polycentric urban regions: identification, profiling and transformation in the Randstad and RhineRuhr. European Planning Studies, 24(11), 2036-2056. https://doi.org/10.1080/09654313.2016.1228832

Hall, S. (1996). 'Who needs "identity"?'. In S. Hall \& P. du Gay (Eds.), Questions of Cultural Identity. London: SAGE.

Jones, C., \& Munday, M. (2001). Blaenavon and UN World Heritage Site Status: Is Conservation of Industrial Heritage a Road to Local Economic Development? Regional Studies, 35(6), 585-590. 
Keil, A., \& Wetterau B. (2013). Metropolis Ruhr. A Regional Study of the New Ruhr. Essen: Regionalverband Ruhr.

Knapp, W. (1998). The Rhine-Ruhr area in transformation: Towards a European metropolitan region? European Planning Studies, 6(4), 379-393. https:// doi.org/10.1080/09654319808720469

Krzysztofik, R. (2015). Like Phoenix from the ashes, like David and Goliath... Niwka - a story of decline, rebirth and political confrontations. In R. Krzysztofik \& M. Dymitrow (Eds.), Degraded and restituted towns in Poland: Origins, development, problems. Gothenburg: University of Gothenburg, 143-158.

Krzysztofik, R., Dymitrow M., Szmytkie, R., KantorPietraga I., Pełka-Gościniak J., \& Spórna T. (2015). Environmental hazards and urban abandonment: case studies and typological issues. Geografiska Annaler: Series B, Human Geography, 97(4), 291308. https://doi.org/10.1111/geob.12082

Mihaylov, V., \& Runge, J. (2018). Potencjał aplikacyjny badań nad tożsamością terytorialną. Rozwój Regionalny i Polityka Regionalna, 43, 53-70.

Murzyn-Kupisz, M., \& Gwosdz, K. (2011). The changing identity of the Central European city: the case of Katowice. Journal of Historical Geography, 37(1), 113-126. https://doi.org/10.1016/j.jhg.2010.04.001

Musterd, S., \& van Zelm, I. (2001). Polycentricity, households and the identity of places. Urban Studies, 38 (4), 679-696. https://doi.org/10.1080/o0420980120035286

Nawrocki, T. (2006). Trwanie $i$ zmiana lokalnej społeczności górniczej na Górnym Ślasku. Katowice: Wydawnictwo Uniwersytetu Śląskiego.

Pasternak, J. (2008). Essen-Katernberg: Image und Identität und die sozialen Probleme eines "Stadtteils mit besonderem Erneuerungsbedarf'. In A. Schwarz (ed.) Industriekultur, Image, Identität: Die Zeche Zollverein und der Wandel in den Köpfen. Essen: Klartext, 69-122.

Pumain, D. (1992). Urban networks versus urban hierarchies? Environment and Planning A, 24,1377-1380.

Robertson, D., McIntosh, I., \& Smyth, J. (2010). Neighborhood identity: The path dependency of class and place. Housing, Theory and Society, 27(3), 258-273. https://doi.org/10.1080/14036090903326429

Runge, A., \& Runge, J. (2015). Modele przestrzeni społecznej złożonych układów osadniczych (wybrane aspekty teoretyczno-empiryczne). In M. Soja \& A. Zborowski (Eds.), Miasto $w$ badaniach geografów, t. 2. Kraków: Instytut Geografii i Gospodarki Przestrzennej Uniwersytetu Jagiellońskiego, 207-226.

Spórna, T. (2018). The suburbanisation process in a depopulation context in the Katowice conurbation, Poland. Environmental \& Socio-economic Studies, 6(1), 57-72. https://doi.org/10.2478/environ-2018-0007

Srokowski, S. (1948). Podział administracyjny Rzeczypospolitej Polskiej. Warszawa: ZZPSTiUP.

Stankiewicz, B. (2014). Dziedzictwo kulturowe przemystu i struktur osadniczych w obszarze Aglomeracji Górnoślaskiej. Gliwice: Wydawnictwo Politechniki Śląskiej.

Strangleman, T. (2001). Networks, Place and Identities in Post-Industrial Mining Communities. International Journal of Urban and Regional Research, 25(2), 253-267. https://doi.org/10.1111/1468-2427.00310

Terlouw, K. (2012). From thick to thin regional identities? GeoJournal, 77, 707-721. https://doi.org/10.1007/ s10708-011-9422-X

Terlouw, K. (2018). Transforming identity discourses to promote local interests during municipal amalgamations. GeoJournal, 83, 525-543. https://doi. org/10.1007/s10708-017-9785-8

Van Houtum, H., \& Lagendijk, A. (200o). Contextualising regional identity and imagination in the construction of polycentric urban regions: The case of the Ruhr area and the Basque country. Urban Studies, 38(4), 747-767. https://doi. org/10.1080/00420980120035321

Wódz, K. (1998). Workers' Communities of Upper Silesia in the Face of Restructuring Process. In K. Wódz K (Ed.) Social Aspects of Reconstruction of Old Industrial Regions in Europe. Katowice: Silesia University Publishing House, 162-204. 